\title{
Mean Performance of Genotypes for Protein and Fiber Content in Dolichos Bean (Dolichos lablab L. var. typicus Prain) Germplasm
}

\author{
K. Jyothi Reddy ${ }^{1^{*}}$, B. Neeraja Prabhakar ${ }^{2}$, P. Saidaiah ${ }^{3}$ and S.R. Pandravada ${ }^{4}$
}

${ }^{1}$ College of Horticulture, SKLTSHU, Rajendranagar, Hyderabad-500030, Telangana, India

${ }^{2}$ Department of Horticulture, College of Agriculture, Professor Jayashankar Telangana State Agriculture University, Rajendranagar, Hyderabad-500030, Telangana, India

${ }^{3}$ Department of Genetics and Plant Breeding, College of Horticulture, SKLTSHU, Rajendranagar, Hyderabad-500030, Telangana, India

${ }^{4}$ Economic Botany, NBPGR Regional Station, Rajendranagar, Hyderabad-500030, Telangana, India

*Corresponding author

\section{A B S T R A C T}

\section{Keywords}

Dolichos bean, Fiber content, Mean performance and protein content

Article Info

Accepted:

04 February 2019

Available Online:

10 March 2019
Thirty five genotypes of dolichos bean (Dolichos lablab L. var. typicus Prain) germplasm lines were evaluated for nutritive value of protein and fiber content in pods at Vegetable Research Station, Agriculture Research Institute, Rajendranagar, Hyderabad during August, 2016 to March, 2017. Genetic improvement in dolichos bean crop is a continuous demand for protein content of pods for different agro-climatic regions. From this study analysis of variance revealed that there is significant differences between genotypes indicating presence of sufficient amount of variability in two qualitative characters studied. Protein content (18.241) and fiber content (48.272) in pod showed maximum variability indicating the scope for selection of initial breeding material for further improvement. Among 35 genotypes studied, performance of PSRJ-13039 (25.09\%) showing maximum protein content in pods $(25.09 \%)$, while the lowest protein content in pods was recorded in IC-546388 (15.41\%). Lowest fiber content was recorded in IC-427424 (10.52\%). Considering protein content and fiber content in pods the selected germplasm may be used as parental source for the development of superior dolichos bean varieties for commercial cultivation and may be released as a variety.

\section{Introduction}

Dolichos bean (Dolichos lablab L. var. typicus Prain) $(2 \mathrm{n}=2 \mathrm{x}=22)$ belongs to family Leguminaceae. It is one of the important indigenous legume vegetables grown in India for its tender green pods, mature fresh green seeds and dry seeds. It occupies a unique position among the legume vegetables with the consumption of the immature green pods as a vegetable and dry seed as a pulse.

The crop prefers relatively cool season, starts flowering in August-September and fruiting in winter (October) and continues indeterminately in spring (February) (Savitha, 
2008). The pods are naturally rich in carbohydrates, proteins, fat and fibers, as well as minerals which include $\mathrm{Ca}, \mathrm{P}$ and $\mathrm{Fe}$ (Naeem et al., 2009). The protein content of pods and seeds ranges from 10-19\% and 15$25 \%$ respectively.

Genetic improvement in dolichos bean crop is a continuous demand for protein content of pods for different agro-climatic regions. Keeping the above points, the present investigation is taken up to study protein and fiber content of pods in dolichos bean genotypes.

\section{Materials and Methods}

Thirty five dolichos bean germplasm lines along with the three checks were grown in Randomized Block Design with two replications were evaluated. Thirty five genotypes viz, IC-261010, IC-383197, IC384066, IC-413709, IC-413710, IC-424813, IC-426988, IC-427424, IC-427428, IC427436, IC-427462, IC-446571, IC-446573, IC-446581, IC-446583, IC-446584, IC446591, IC-546349, IC-546376, IC-546387, IC-546388, IC-565181, IC-598467, NSB2010/029, NSJ/NAIP/192, PSR-13183, PSRJ13039， PSRJ-13114-2， RJR-03， RJR-387, SGD136, SNJ-11-068, RND-1 (check), Arka Jay (check) and Arka Vijay (check).

The crude protein content of the sample was estimated according to the micro Kjeldhal method AOAC. (2005) calculated as protein nitrogen product and multiplied with 6.25 to obtain the protein content.

The fiber content of samples was determined by boiling with $1.25 \%$ dilute $\mathrm{H}_{2} \mathrm{SO}_{4}$, washed with water, further boiled with $1.25 \%$ dilute $\mathrm{NaOH}$ and the remaining residue after digestion was taken as crude fiber AOAC. (1990).
The mean replicated data collected on 19 quantitative traits was subjected to analysis of variance by the methods outlined by Panse and Sukhatme (1985) using the mean values of five random plants in each replication from all genotypes to find out the significance of genotypes effect.

\section{Results and Discussion}

\section{Analysis of variance}

The analysis of variance (Table 1) revealed significant differences between genotypes for the characters indicating presence of sufficient amount of variability in the characters studied. Variability was observed for protein content (18.241) and fiber content (48.272) indicating the scope for selection of initial breeding material for further improvement based on these characters.

\section{Protein content $(\%)$}

Protein content in dolichos bean genotypes (Table 2) was ranged from $15.41 \%$ to 25.09 $\%$ with a grand mean of $19.51 \%$. The highest protein content $25.09 \%$ was recorded in PSRJ-13039, while the lowest was recorded in IC-546388 (15.41 \%). Three genotypes namely IC-427462 (24.15\%), RND-01 (24.28 $\%)$ IC-427428 (24.76 \%) recorded statistically at par values with the PSRJ$13039(25.09 \%)$.

Out of 35 dolichos bean genotypes, sixteen genotypes produced significantly highest protein content as compared to the grand mean. Two genotypes IC-427428 (24.76\%) and PSRJ-13.39 (25.09 \%) recorded significantly highest protein content over the check variety RND-1 (24.28 \%). These results are in concurrence with the findings of those reported by Parmar et al., (2013), Chaitanya et al., (2014) and Verma et al., (2015). 
Table.1 Analysis of variance for two qualitative traits in 35 genotypes of dolichos bean

\begin{tabular}{|c|l|c|c|c|}
\hline \multirow{2}{*}{$\begin{array}{l}\text { Sl. } \\
\text { no }\end{array}$} & Character & \multicolumn{3}{|c|}{ Mean sum of squares } \\
\hline & & Replication $(\mathbf{d f}=\mathbf{1})$ & $\begin{array}{c}\text { Treatments } \\
(\mathbf{d f}=\mathbf{3 4})\end{array}$ & Error $(\mathbf{d f}=\mathbf{3 4})$ \\
\hline $\mathbf{1 .}$ & Protein content (\%) & 2.662 & $18.241^{* *}$ & 0.888 \\
\hline $\mathbf{2 .}$ & Fiber content (\%) & 1.037 & $48.272^{* *}$ & 1.237 \\
\hline
\end{tabular}

*and ** significant at $\mathrm{P}=0.05$ and $\mathrm{P}=0.01$ level of significance respectively

Table.2 Mean values of 35 genotypes for protein and fiber content in dolichos bean genotypes

\begin{tabular}{|c|c|c|c|}
\hline Sl.no & Genotype & Protein content (\%) & Fiber content (\%) \\
\hline 1. & IC-261010 & 20.91 & 17.91 \\
\hline 2. & IC-383197 & 16.72 & 21.15 \\
\hline 3. & IC-384066 & 21.78 & 15.26 \\
\hline 4. & IC-413709 & 20.09 & 24.91 \\
\hline 5. & IC-413710 & 21.11 & 13.82 \\
\hline 6. & IC-424813 & 18.97 & 13.06 \\
\hline 7. & IC-426988 & 18.75 & 25.68 \\
\hline 8. & IC-427424 & 17.53 & 10.52 \\
\hline 9. & IC-427428 & 24.76 & 15.83 \\
\hline 10. & IC-427436 & 13.93 & 14.79 \\
\hline 11. & IC-427462 & 24.15 & 15.49 \\
\hline 12. & IC-446571 & 17.11 & 19.92 \\
\hline 13. & IC-446573 & 15.80 & 13.17 \\
\hline 14. & IC-446581 & 17.88 & 27.12 \\
\hline 15. & IC-446583 & 17.93 & 15.49 \\
\hline 16. & IC-446584 & 20.06 & 17.92 \\
\hline 17. & IC-446591 & 18.14 & 25.32 \\
\hline 18. & IC-546349 & 18.47 & 23.70 \\
\hline 19. & IC-546376 & 17.13 & 28.35 \\
\hline 20. & IC-546387 & 16.75 & 17.66 \\
\hline 21. & IC-546388 & 15.41 & 21.48 \\
\hline 22. & IC-565181 & 16.41 & 20.46 \\
\hline 23. & IC-598467 & 17.20 & 16.44 \\
\hline 24. & NSB-2010/029 & 15.74 & 13.67 \\
\hline 25. & NSJ/NAIP/192 & 22.82 & 19.89 \\
\hline 26. & PSR-13183 & 22.94 & 22.26 \\
\hline 27. & PSRJ-13039 & 25.09 & 28.02 \\
\hline 28. & PSRJ-13114-2 & 16.70 & 25.53 \\
\hline 29. & RJR-03 & 23.00 & 26.14 \\
\hline 30. & RJR-387 & 18.77 & 18.29 \\
\hline 31. & SGD-136 & 19.84 & 14.64 \\
\hline 32. & SNJ-11-068 & 22.26 & 15.53 \\
\hline 33. & RND-01 () & 24.28 & 21.87 \\
\hline 34. & ARKA JAY @ & 22.22 & 15.17 \\
\hline \multirow[t]{5}{*}{35.} & ARKA VIJAY @) & 22.30 & 18.49 \\
\hline & MEAN VALUES & 19.51 & 19.28 \\
\hline & S.E of mean & 0.66 & 0.78 \\
\hline & C.D 5\% & 1.91 & 2.26 \\
\hline & C.D 1\% & 2.57 & 3.03 \\
\hline
\end{tabular}




\section{Fiber content (\%)}

Fiber content in dolichos bean genotypes (Table 2) was ranged from $10.52 \%$ to 28.35 $\%$ with a grand mean of $19.28 \%$. The highest fiber content was recorded in RDG-25 (28.35 $\%$ ), while the lowest fiber content was recorded in RDG-13 (10.52 \%). None of the genotypes recorded statistically at par values with RDG-13 (10.52 \%). Out of 35 dolichos bean genotypes, 15 genotypes produced significant and highest fiber content compared to the grand mean. Ten genotypes i.e. IC413709 (24.91\%), IC-426988 (25.68\%), IC$446581(27.12 \%)$, IC-446591 (25.32\%), IC546349 (23.70\%), IC-546376 (28.35\%), PSR-13183 (22.26 \%), PSRJ-13039 (28.02 $\%)$, PSRJ-13114-2 (25.53 \%) and RJR-03 $(26.14 \%)$ recorded significantly highest fiber content over the check variety RND-1 (21.87 $\%)$.

In conclusion, protein content (18.241) and fiber content (48.272) in pods showed variance among the qualitative characters indicating the scope for selection of initial breeding material for further improvement. Among 35 genotypes, PSRJ-13039 showing maximum protein content $(25.09 \%)$. Lowest fiber content was recorded in IC-427424 $(10.52 \%)$. Hence these genotypes tested for their stable performance in different locations by pedigree and released for commercial cultivation after multilocation trials. The selected germplasm may be as parental source for the development of superior dolichos bean varieties for commercial cultivation.

\section{References}

AOAC. 1990. Official methods of analysis for fiber. Association of Official Analytical Chemists. $14^{\text {th }}$ edition. Washington DC.USA

AOAC. 2005. Official methods of analysis for protein. Association of Official
Analytical Chemists. $18^{\text {th }} \quad$ edition. Arlington VA 2209.

Chaitanya, V, Reddy, R.V.S.K, Pandravada, S.R, Sujatha, $M$ and Kumar, A.P. 2014. Correlation and Path Coefficient Analysis in dolichos bean (Dolichos lablab L. var. typicus prain) genotypes Plant Archives Vol. 14 No.1, pp.537540

Choudhary, J, Kushwah, S. S, Singh, O. P and Naruka. I. S.2016. Studies on genetic variability and character association in Indian bean [lablab purpureus (L.) Sweet] Legume Research, 39(3)2016:336-342

Magalingam, Yassin, M and Kumar, S. R. 2013. Genetic variability and character association in dolichos bean, SAARC J. Agri., 11(2): 161-171 (2013) TNAU, Karaikal-609 603, Tamil Nadu, India

Naeem, M, Khan, M. M. A and Siddiqui, M. H. 2009. Triacontanol stimulates nitrogen fixation, enzyme activities, photosynthesis, crop productivity and quality of hyacinth bean (Lablab purpureus L.). Scientia Horticulture 121(4): 389-396.

Panse, V. G and Sukhatme. 1985. Statistical methods for agricultural workers. Indian Council of Agriculture Research, New Delhi. p. 134-192

Parmar, M, Singh, A. P, Dhillon, N. P. S and Jamwal, M. 2013. Genetic variability of morphological and yield traits in Dolichos bean (Lablab purpureus L.). World Journal of Agricultural sciences, 9(1):24-28

Savitha, B. N. 2008. Characterization of Avare (Lablab purpureus L. Sweet) local collections for genetic variability. M.Sc. (Agril.) Thesis. University of Agricultural Sciences, Dharwad.

Verma, A.K, Uma Jyothi, $\mathrm{K}$ and Rao, A.V.D.2015. Variability and character 
association studies in Dolichos bean (Lablab purpureus L.) genotypes

Indian Journal of Agricultural. Research, 49(1): 46-52.

\section{How to cite this article:}

Jyothi Reddy, K., B. Neeraja Prabhakar, P. Saidaiah and Pandravada, S.R. 2019. Mean Performance of Genotypes for Protein and Fiber Content in Dolichos Bean (Dolichos lablab L. var. typicus Prain) Germplasm. Int.J.Curr.Microbiol.App.Sci. 8(03): 150-154. doi: https://doi.org/10.20546/ijcmas.2019.803.021 